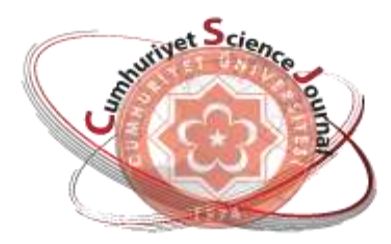

e-ISSN: 2587-246X

ISSN: $2587-2680$

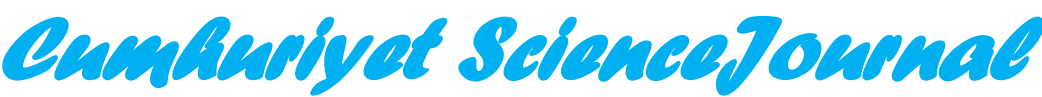

$\cos 7$

Cumhuriyet Sci. J., Vol.40-1(2019) 102-107

\title{
Determination of Outdoor Absorbed Gamma Dose Rates of Kahramanmaraş Province, Turkey
}

\author{
Muhammet KARATAŞLI \\ Cukurova University, Faculty of Arts and Sciences, Department of Physics, Adana, TURKEY \\ Received: 19.09.2018; Accepted: 18.12.2018 \\ http://dx.doi.org/10.17776/csj.461485
}

\begin{abstract}
Outdoor absorbed gamma dose rates were measured in 118 different regions at a height of $1 \mathrm{~m}$ above the ground in the gonad (genitals) level in humans in Kahramanmaraş province and its vicinity using Eberline portable detector. Outdoor gamma dose rates varied from $32.7 \mathrm{nGy} / \mathrm{h}$ and $96.4 \mathrm{nGy} / \mathrm{h}$ with an arithmetic average of $64.8 \mathrm{nGy} / \mathrm{h}$. The average value of the corresponding annual effective dose rate was estimated as $79.5 \mu \mathrm{Sv} / \mathrm{y}$. Lifetime cancer risk values estimated according to ICRP 103, BEIR VII and ICRP 60 were found to be $0.032,0.036$ and 0.040 respectively.
\end{abstract}

Keywords: Cancer risk, effective dose, gamma dose.

\section{Türkiye'nin Kahramanmaraş İlinde Soğurulan Gama Doz Seviyesinin Belirlenmesi}

Özet. Kahramanmaraş İli ve çevresinde 118 farklı bölgede açık havada soğurulan gama radyasyon doz düzeyini belirlemek için insanlarda gonad (üreme organları) hizasında yerden yaklaşı $1 \mathrm{~m}$ yükseklikte Eberline marka portatif dedektörle ölçümler alınmıştır. Her bölgede ölçümler alınırken 5 metre yarıçapında üç farklı okuma yapılmış ve bu üç değerin ortalaması alınarak her bir ölçüm bölgesi için gama doz değerleri belirlenmiş̧ir. Kahramanmaraş ili geneli için gama dozu ölçümlerinin değeri 32,7 nGy/s ile 96,4 nGy/s arasında bulunmuş olup, aritmetik ortalaması $64,8 \mathrm{nGy} / \mathrm{s}$ olarak hesaplanmıştır. Soğurulan gama radyasyon dozu kullanılarak hesaplanan yıllık etkin doz eşdeğerinin ortalama değeri ise 79,5 $\mu \mathrm{Sv} / \mathrm{y}$ olarak hesaplanmıştır. Kahramanmaraş ilinde yaşam boyu kanser risk değerleri ICRP 103, BEIR VII ve ICRP 60 için yüzdelik ortalamaları sırasıyla $0,032,0,036$ ve 0,040 olarak bulunmuştur. Elde edilen sonuçlarla Türkiye'de diğer illerde yapılan benzer çalışmaların sonuçları ve dünya ortalamaları ile karşıllaştırılmıştır.

Anahtar Kelimeler: Kanser riski, etkindoz, gama doz.

\section{INTRODUCTION}

During the life of the people, they live inthe environment in which they live, depending on their environment and quality of life significantly natural radiation, nuclear weapons experiments, nuclear plant accidents, nuclear power plant emissions and leaks as a result of artificial radiation sources and internal and external irradiation as a result of radiation under the influence of [1].
Radionuclides with higher half-life such as ${ }^{238} \mathrm{U}$ an ${ }^{232} \mathrm{Th}$ radioactive uranium series and radioactive potassium $\left({ }^{40} \mathrm{~K}\right)$ are naturally present from the formation of the earth's crust. The gamma rays that they broadcast form a large part of the environmental radiation. Their effect on these gamma rays depends on the concentration of radioactive elements in their territory. The activity concentrations of ${ }^{238} \mathrm{U},{ }^{232} \mathrm{Th}$ and ${ }^{40} \mathrm{~K}$ vary with 
soil and rock types. Therefore, the absorbed gamma dose rate measured in the outdoor air is closely related to the concentrations of radionuclei in the soil $[2,3]$.

The main purpose of environmental radiation measurements is to determine the radiation type and dose of people from environmental sources and to evaluate the risk they will generate. In this, the environmental concentrations of radionuclides, which constitute the sources of natural radiation, and the effects of radiation on biological systems, especially in humans, need to be determined. In addition, the relationship between the radionuclides in the environment and the radiation dose that people receive from these sources should also be determined. However, after such research, it can be decided whether a region is suitable for natural radiation or not. The difference in the concentration of radioactivity in the earth crust is one of the most important factors affecting the level of radiation. The differentiation of the radioactivity concentration varies depending on the geographic and geological structure of the region, the mineralogical structure of the rock and its soils and the elevation above sea level [4].

In addition to the dose and type of radiation in the world and Turkey as human research for assessing the risk they might have on health it is made. After the Chernobyl nuclear accident in 1986, a number of studies aimed at determining the level of natural background radiation in Turkey, especially in regions affected by this accident could have been made $[5,6]$.
However, despite the majority in Turkey take place in the Mediterranean region, located in the northern and northeastern parts of Eastern Anatolia Region does not have a sufficient number of studies to determine the gamma dose levels of Kahramanmaras. For this reason, this study was conducted to measure, evaluate and understand. This data will also be useful in assessing possible future environmental pollution.

\section{MATERIALS \& METHODS}

\section{Geology of the survey area}

Kahramanmaraş, $37^{\circ} 11^{\prime}$ and $38^{\circ} 36^{\prime}$ north latitude of $36^{\circ} 15^{\prime}$ and $37^{\circ} 42^{\prime}$ east longitude is between 14 $457 \mathrm{~km}^{2}$ area in terms of area size and Turkey's 12 largest cities. As seen in Figure 1, although the majority of the Kahramanmaraş province is located in the Mediterranean Region, some parts of the north and northeast are in Eastern Anatolia. The eastern parts of the Çağlayancerit and Pazarc1k districts are within the borders of the Southeastern Anatolia Region. In terms of land structure and altitude, flatness, pit and mountainous areas are numerous [7]. Most of the landforms consist of collapsed areas between the mountains, which are the extensions of the Southeast Taurus Mountains and these mountains. The vast majority of the plains are located around the Ceyhan Valley. The plateaus are located between the mountainous areas and the plains. $59.7 \%$ of the province of Kahramanmaraş consists of mountains, $24 \%$ plateaus and $16.3 \%$ plains. The altitude ranges from 350 meters to 3090 meters [8].

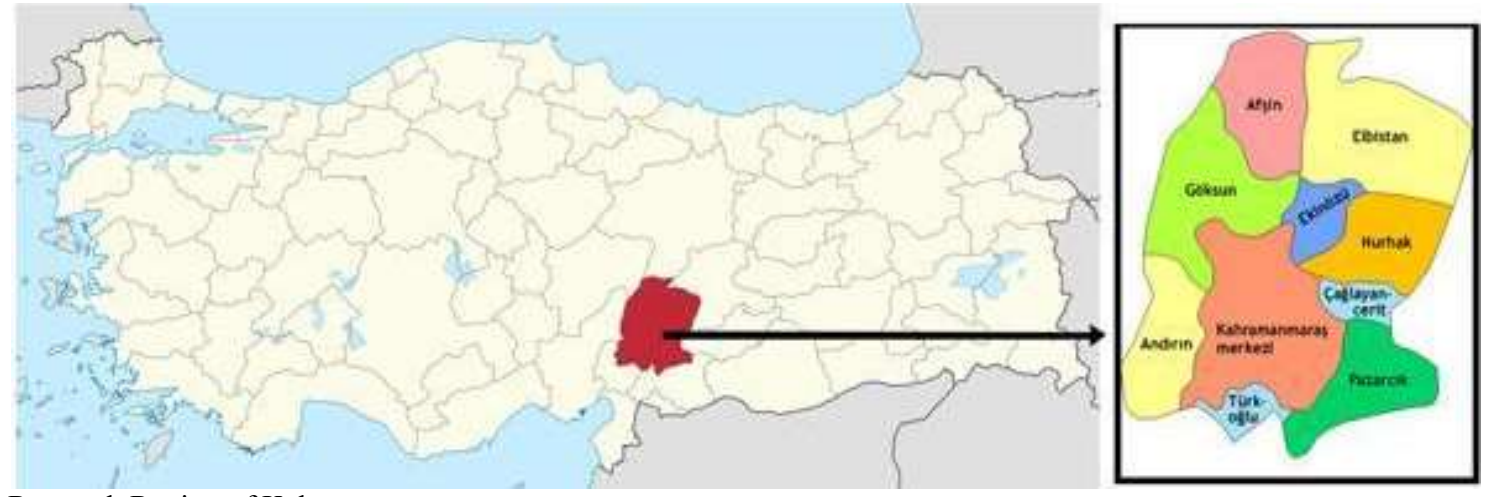

Figure 1.Research Region of Kahramanmaraş. 


\section{Gamma Scintillation Detector}

In this study, Eberline Smart Portable (ESP-2) model, portable microcomputer and a SPA-6 plastic scintillation detector connected device were used to determine the external gamma radiation levels. ESP-2 is a device specially designed for radiation measurements, which can record the measured information and then transfer the information recorded to a connected printer. Allows multiple reads (over 500) and subsequently a computer can be connected to the printer. The SPA-6 detector is highly sensitive to the detection of radiation emitted from lowactivity radionuclides descending into the ground with fallout with measurements of natural gamma radiation. The ESP-2 has seven multi-function opening switches and a liquid crystal display (LCD), designed as an interface for the user. The data can be given either as scientific or motion point recording and in selectable measurement units [9].

Scintillation detectors consist of a substance used as a scintillator and a photon amplifier tube connected directly behind it. Ionizing radiation interacts with some of the solid, liquid or gaseous substances, called scintillation phosphorus, resulting in ionization and stimulation. When the energy given to the electron is not enough to detach it from the environment, the electron is emitted and the visible light is released as it returns to its original state. The light emitted by the scintillation phosphors is collected by photon multiplier tubes and converted into voltage pulses. The amplitude of the pulse is proportional to the energy of the radiation. These detectors are used for counting and also for energy separation. Although scintillation phosphors may be in liquid or crystalline form, only crystal ones are still used in radiation control work [9].

In order to minimize measurement errors during the determination of gamma dose values, three readings were made at each measurement point and the mean of these three values were determined and the gamma dose values for each measurement region were determined. The results include contributions from both terrestrial radionuclides and cosmic rays. The portable detector used in the measurements shows the measurement results in $\mu \mathrm{R} / \mathrm{h}$. After getting the average of three different measurements, results were recorded in $\mu \mathrm{R} / \mathrm{h}$ and then the conversion factor of $8.7 \mathrm{nGy} \mu /$ Rwas used to change the unit of $\mu \mathrm{R} / \mathrm{h}$ to the $\mathrm{nGy} / \mathrm{h}[10]$.

\section{Determination of outdoor gamma dose rates}

After getting the average of three different measurements, results were recorded in $\mu \mathrm{R} \mathrm{h}^{-1}$ and then the conversion factor of $8.7 \mathrm{nGy} \mu \mathrm{R}^{-1}$ was used to change the unit of $\mu \mathrm{R} \mathrm{h}^{-1}$ to the $n G y \mathrm{~h}^{-1}$. To obtain the annual effective dose equivalent (AEDE), the following equation was used [11,12].

\section{AEDE $=$ ADRA $x$ DCF $x$ OF $x$}

In this equation, the environmental gamma dose conversion factor is determined as $0.7 \mathrm{~Sv} / \mathrm{Gy}$ and this value does not change for measurements both inside and outside the home. Another factor that should be known in this equation is the Busy Factor, that is, the time that people are exposed to these rays. In the calculations made in this study, it is considered that people spend $20 \%$ of their time in open areas and $80 \%$ in closed areas (occupancy factor is taken as 0.8 for home and 0.2 for outside house). Time is the number of hours in a year $(8760 \mathrm{~s} / \mathrm{y})$. Lifetime cancer risk (ELCR) was calculated using equation $2[11,13]$.

\section{ELCR=AEDE $\mathrm{x}$ DL $\mathrm{x}$ RF}

Here AEDE is the annual effective dose equivalent, DL, mean life expectancy (mean 70 years) and RF is the fatal cancer risk factor in $\mathrm{Sv}^{-}$ 1 , and in this study, the RFs of ICRP 103, BEIRVII [14] and ICRP 60 for the public as $0.057,0.064$ and 0.072 , respectively, have been used [15].

\section{RESULTS AND DISCUSSION}

The absorbed dose rate in air (ADRA) $1 \mathrm{~m}$ above the ground consisting of the terrestrial and the cosmic gamma components was determined as $64,8 \mathrm{nGy} \mathrm{h}^{-1}$ for the entire region. Thereadingsrangedfrom 32,7 to $96,4 \mathrm{nGy} / \mathrm{h}$. The measured outdoor gamma exposure dose rates (GEDR) in $\mu \mathrm{R} / \mathrm{h}$ and absorbed gamma dose rates in air (ADRA) in $n G y / h$ are presented for each distinct of the Kahramanmaraş in Table 1. 
Table 1. Gamma Exposure Dose Rate and Absorbed dose rate for each distinct of the Kahramanmaraş.

\begin{tabular}{|c|c|c|c|c|c|c|}
\hline \multirow[b]{2}{*}{ Distinct } & \multicolumn{3}{|c|}{$\begin{array}{c}\text { GEDR (Gamma Exposure Dose Rate) } \\
(\mu \mathrm{R} / \mathrm{h})\end{array}$} & \multicolumn{3}{|c|}{$\begin{array}{c}\text { ADRA (Absorbed Dose Rate in Air) } \\
\text { (nGy/h) }\end{array}$} \\
\hline & Minimum & Maximum & Mean & Minimum & Maximum & Mean \\
\hline $\begin{array}{l}\text { KahramanmaraşM } \\
\text { erkez }\end{array}$ & 3.75 & 7.90 & 6.44 & 32.7 & 68.8 & 56 \\
\hline Türkoğlu & 5.65 & 6.86 & 6.09 & 49.2 & 59.7 & 53 \\
\hline Pazarcık & 6.27 & 9.60 & 7.07 & 54.6 & 83.6 & 61.5 \\
\hline Çağlayancerit & 7.06 & 10.97 & 7.97 & 61.5 & 95.5 & 69.4 \\
\hline Andirin & 6.60 & 10.39 & 7.96 & 57.5 & 90.4 & 67.3 \\
\hline Afşin & 7.40 & 10.88 & 8.81 & 64.4 & 94.7 & 76.7 \\
\hline Elbistan & 7.52 & 10.32 & 8.32 & 65.5 & 89.8 & 72.5 \\
\hline Göksun & 7.05 & 10.18 & 7.85 & 61.4 & 88.6 & 68.3 \\
\hline Ekinözü & 7.11 & 10.80 & 8.12 & 61.9 & 94.3 & 70.7 \\
\hline Nurhak & 6.40 & 11.08 & 9.22 & 55.7 & 96.4 & 80.3 \\
\hline Region & 3.75 & 11.08 & 7.45 & 32.7 & 96.4 & 64.8 \\
\hline
\end{tabular}

The absorbed gamma dose map obtained as a result of the measurements in Kahramanmaraş province and its districts was drawn. Figure 2 shows the general distribution of the absorbed gamma dose rate throughout the province in the form of an isodose map. Red areas represent areas where Kahramanmaras province and overall absorbed gamma dose doses are high.

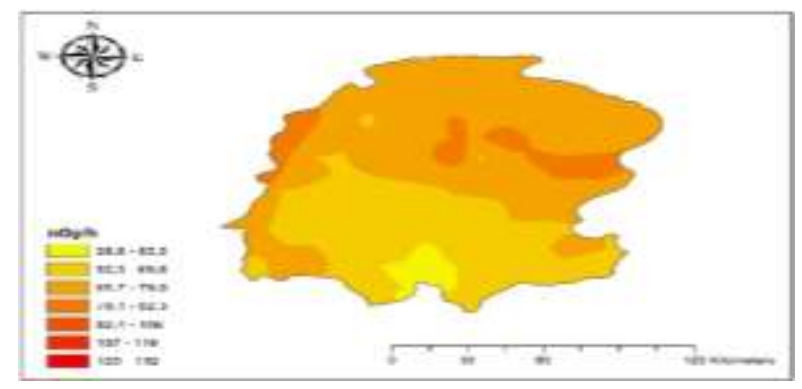

Figure 2.ADRA in Kahramanmaraş.
Table 2 presents the radiation doses (yearly effective dose equivalents) of people exposed to one year during the year and the risk factors for life-long cancer caused by environmental gamma radiation for a year by using absorbed gamma dose values in Kahramanmaras province.

Table 2. The average annual effective dose values and Lifetime cancer risk.

\begin{tabular}{|c|c|c|c|c|}
\hline \multicolumn{5}{|c|}{ Lifetime cancer risk \% } \\
\hline & $\begin{array}{c}\text { AEDE } \\
\text { Annual effective } \\
\text { dose } \\
(\mu \mathrm{Sv} / \mathrm{y})\end{array}$ & ICRP 103 & BEIR VII & ICRP 60 \\
\hline $\begin{array}{c}\text { Kahramanmaraş } \\
\text { Merkez }\end{array}$ & 68.7 & 0.027 & 0.031 & 0.035 \\
\hline Türkoğlu & 65 & 0.026 & 0.030 & 0.033 \\
\hline Pazarcık & 75.4 & 0.030 & 0.034 & 0.038 \\
\hline Cağlayancerit & 85 & 0.034 & 0.038 & 0.042 \\
\hline Andırın & 83 & 0.033 & 0.037 & 0.042 \\
\hline Afşin & 94 & 0.038 & 0.042 & 0.048 \\
\hline Elbistan & 89 & 0.036 & 0.040 & 0.045 \\
\hline Göksun & 84 & 0.034 & 0.038 & 0.042 \\
\hline Ekinözü & 87 & 0.035 & 0.039 & 0.044 \\
\hline Nurhak & 98.5 & 0.039 & 0.044 & 0.050 \\
\hline Region & 79.5 & 0.032 & 0.036 & 0.040 \\
\hline
\end{tabular}


The annual effective dose equivalent calculated using the absorbed gamma dose measurement varies between $40.1 \mu \mathrm{Sv} / \mathrm{y}$ and $11.2 \mu \mathrm{Sv} / \mathrm{y}$, but the average value was found to be $79.570 \mu \mathrm{Sv} / \mathrm{y}$. As can be seen in Table 3, the annual effective dose equivalent is $79.5 \mu \mathrm{Sv} / \mathrm{y}$, the world average is greater than $70 \mu \mathrm{Sv} / \mathrm{y}[12]$.

Table 3. Absorbed Dose Rates in Air (ADRA) in close cities to region and worldwide averages.

\begin{tabular}{lcc}
\hline & $\begin{array}{c}\text { ADRA } \\
\text { (AbsorbedDose Rate) } \\
(\mathbf{n G y / h )}\end{array}$ & $\begin{array}{c}\text { AEDE } \\
\text { (Annualeffectivedose) } \\
(\boldsymbol{\mu S v / y )}\end{array}$ \\
\hline İstanbul [16]. & 65 & 79.7 \\
Kastamonu [17]. & 54.81 & 67.21 \\
Şanliurfa [18]. & 60.9 & 74.7 \\
Kirklareli [19]. & 118 & 144.7 \\
Tekirdağ [20]. & 43.85 & 53.77 \\
Çanakkale [21]. & 66.4 & 81.4 \\
Çankırı [22]. & 69.6 & 87.7 \\
Trabzon [23]. & 59 & 72.4 \\
Yalova [24]. & 84 & 103 \\
Balıkesir [25]. & 127 & 155.8 \\
Kahramanmaraş & 64.8 & 79.5 \\
Worldwide [12]. & 60 & 70 \\
\hline
\end{tabular}

\section{REFERENCES}

[1]. Karataşl1, M., Özer, T., Investigation of Radiation Activity Growing Peanuts in Osmaniye, Süleyman Demirel University, Journal of Natural and Applied Sciences, 21, 3 (2017) 1017-1023.

[2]. Beck, H.L., The Natural Radiation Environment II. USERDA Conf.-720805-P2, The Physics of Environmental Gamma Radiation Fields, (1982), 101-104.

[3]. National Council on Radiation Protection and Measurements, Environmental Radiation Measurement, NCRP Report No. 50, ISBN. 0- 913392-32-4, (1977).

[4]. Eisenbud, M., Environmental Radioactivity, Third Edition, ISBN. 0-12-235153, Academic Pres, Inc., London, 1987.

[5]. TAEK, Post-Chernobyl Radiation and Radioactivity measurements in Turkey, Atomic Energy Agency Ankara, 1998.

[6]. TAEK, Post-Chernobyl Radiation and Radioactivity measurements in Turkey. Turkey Atomic Energy Agency, Ankara, 2006.

[7]. Tursun, N., Tursan, A. Ö., Kaçan, K., Determination of Weeds in Cotton Fields in Kahramanmaraş, Turkey, KSU Journal of Science and Engineering 7-1 (2004) 92-95.

[8]. Gürbüz,M., Yıldırım,U., Belli A., Metropolitan Municipality Analysis on Scale of Kahramanmaraş. Adnan Menderes University, Journal of Institute of Social Sciences, 1-1, Special Issue, (2014) 102-135.
[9]. Değerlier, M., Determination of Enviromental Natural Radioactivity of Adana and The Annual Effective Dose Equivalent Due to Natural Radiation, Ph.D. Thesis, Department Of Physics Institute Of Natural And Applied Sciences University of Çukurova, Adana, 2007.

[10].Baykara, O. The determinations of natural radioactivity in the intersect zone of the North Anatolian Fault and East Anatolian. $\mathrm{PhD}$ thesis, Fault, Firat University Graduate School of Natural and Applied Science, Physics Department, Elazig, Turkey (in Turkish) 2005.

[11].Karataşl1, M., Turhan, Ş., Varinlioğlu, A., Yeğingil, Z.: Natural and fallout radioactivity levels and radiation hazard evaluation in soil samples. Environ. Earth Sci., 75-5 (2016) 19.

[12].UNSCEAR Report of the United Nations Scientific Committee on the Effects of Atomic Radiation, Sources, Effects, and Risks of Ionizing Radiation. United Nations sales publication, New York. United Nations, 2000.

[13].UNSCEAR UNSCEAR, Report of the United Nations Scientific Committee on the Effects of Atomic Radiation, Sources, Effects, and Risks of Ionizing Radiation. United Nations sales publication, New York. United Nations, 2008.

[14].NCR, National Academy of Sciences. National Research Council Committee to 
Assess Health Risks from Exposure to Low Levels of Ionizing Radiation. Report of VII, 2006

[15].ICRP Publication 103 Recommendations of the ICRP: Annals of the ICRP (International Commission on Radiological Protection), 37 (2007).2-4

[16].Karahan, G.,Bayulken, A., Assesment of Gamma Dose Rates Around Istanbul. Journal of Envrionmental Radioactivity, 47-2 (2000) 213-221.

[17].Kam, E., Bozkurt, A., Environmental radioactivity measurements in Kastamonu region of northernTurkey. Applied Radiation and Isotopes, 65 (2007) 440-444.

[18].Bozkurt, A., Yorulmaz, N., Kam, E., Karahan, G. And Osmanlıoğlu, A. E., Assessment of environmental radioactivity for Şanliurfa region of Southeastern Turkey. Radiation Measurements, 42-8 (2007) 13871391.

[19].Taskin, H. Karavus, M., Ay, P., Topuzoglu, A., Hidiroglu, S, Karahan, G., Radionuclide concentrations in soil and lifetime cancer risk due to gamma radioactivity in Kirklareli, Turkey, Journal of Environmental Radioactivity, 100 (2009) 49-53.

[20].Kam, E., Yarar, Y., Bozkurt, A., A study of background radioactivity level for Tekirdag.
Turk Radiat Prot Dosimetry, 138 (2010) 4044.

[21].Kam, E., Bozkurt, A., Ilgar, R., A study of background radioactivity level for Canakkale, Turkey. Environ. Monit. Assess, 168 (2010) 685-690.

[22].Kapdan, E., Taşkın, H., Kam, E., Osmanlığlu, A.E., Karahan, G., Bozkurt A., 2011. A study of environmental radioactivity measurements for Cankiri, Turkey. Radiation Protection Dosimetry, 150-3 (2010) 398-404.

[23].Kurnaz, A., Kucukomeroglu, B., Damla, N., Cevik, U., Radiological maps for Trabzon, Turkey. J. Environ. Radioactiv. 102 (2011) 393-399.

[24].Kapdan, E. , Varinlioglu , A. Karahan, G., Radioactivity Levels and Health Risks due to Radionuclides in the Soil of Yalova, Northwestern Turkey, 5-4 (2011) 837-846.

[25].Kapdan, E., Varinlioglu , A. Karahan, G., Outdoor radioactivity and health risks in Balikesir, Northwestern Turkey, Radiation Protection Dosimetry, 148-3 (2012) 301-309.

[26].ICRP, The International Commission on Radiological Protection, ICRP Publication 60. Recommendations of the International Commission on the Radiological Protection, Pergamon Press Inc., ICRP 1990, USA. 